\title{
Evaluation of Yeast Isolates as Indicators for Measurement of Bioavailable Cadmium
}

\author{
Soraya Tra-ngan $^{1}$, Wilailak Siripornadulsil ${ }^{2}$ and Surasak Siripornadulsil ${ }^{3}$
}

\begin{abstract}
Cadmium (Cd) in the environment significantly increased from the anthropogenic activities and its detection in the environment is essential. This study aims to characterize the phenotypic changes of 34 yeast isolates when grown with and without $\mathrm{Cd}$. Seven isolates were able to grow on Endo agar (EA) with 30 $\mu \mathrm{g} / \mathrm{mL}$ kanamycin (KAN) and Congo red agar (CRA) with $100 \mu \mathrm{g} / \mathrm{mL}$ vancomycin (VAN) when treated with $0-10 \mathrm{mg} / \mathrm{L} \mathrm{Cd}$. On EA with KAN, K12 showed a pink colony on agar without Cd but colorless on medium with Cd. Two isolates (K9 and K11) changed the color from orange to red colonies on CRA with VAN and $0-1 \mathrm{mg} / \mathrm{L} \mathrm{Cd}$ after incubation for $48 \mathrm{~h}$. The observed visible colors of yeast growth using different media indicated their certain sensitivity and specificity to bioavailable $\mathrm{Cd}$. Thus, additional growth conditions will be further investigated and evaluated as the indicators of $\mathrm{Cd}$ in contaminated samples.
\end{abstract}

Index Terms - Cadmium, Yeast, Phenotypic change, Sensitivity, Specificity, Biodetection.

\section{INTRODUCTION}

CADMIUM (Cd) is one of heavy metals that is highly toxic and widespread in the environment in recent decades and trends to accumulate in soils due to its low mobility and non-degradability. The environmental contamination with $\mathrm{Cd}$ has been increased from the anthropogenic activities which mainly caused by batteries industry, pigments, metal coatings plastics and mining [1]. In the environment, $\mathrm{Cd}$ commonly forms a complex with lead, zinc, sulfide and carbonate and normally is not present as a pure form [2]. Cd is efficiently bound by high molecular weight proteins including albumin and by non-protein sulfhydryl groups in the human body. $\mathrm{Cd}$ can accumulate in the kidney and liver and $\mathrm{Cd}$ increased in the kidney can also result in a higher calcium excretion leading to a higher risk of kidney stones [3][4].

The measurement of heavy metals effecting on the health and environment has been the subject of many studies. Cd is widely spread in the environment and can interact with the soil and living organisms through several pathways [5]. Thus, the effective detection of $\mathrm{Cd}$ in the contaminated samples could help reducing risk of living organism to its toxicity. A biosensor

Soraya Tra-ngan1 is with the Department of Microbiology, Faculty of science, Khon Kaen University, 123 Mittapap Road, Tambon Nai-Muang District, Khon Kaen, 40002 Thailand..

Wilailak Siripornadulsil2 is with the Department of Microbiology, Faculty of science, Khon Kaen University, 123 Mittapap Road, Tambon Nai-Muang District, Khon Kaen, 40002 Thailand.

Surasak Siripornadulsil3 is with the Department of Microbiology, Faculty of science, Khon Kaen University, 123 Mittapap Road, Tambon Nai-Muang District, Khon Kaen, 40002 Thailand. can be used to detect the bioavailability of heavy metals concentration using microbial and biomolecules, one of the most significant parameters regarding the environmental aspects [6]. Most importantly, their advantages include bioavailable measurement, inexpensive, sensitive and suitable for a field work [7].

In this study, phenotypic characterization of yeast grown on different media treated or untreated with $\mathrm{Cd}$ will be investigated. We proposed that the phenotypic change of yeast according to $\mathrm{Cd}$ response could be observed and indicate the amount of bioavailable $\mathrm{Cd}$ in the yeast cell. So, the altered phenotypes could be applied and developed as a tool for $\mathrm{Cd}$ detection.

\section{MAterials AND Methods}

\section{A. Yeast and selective media}

The total of 34 yeast isolates were cultivated in nutrient broth (NB) with shaking $150 \mathrm{rpm}$ at $30^{\circ} \mathrm{C}$ until it reached a mid-log phase. Then, $5 \mu \mathrm{L}$ of yeast cell suspensions were dropped onto two types of media, Endo agar (1\% peptic digest of animal tissue, $1 \%$ lactose, $0.25 \%$ dipotassium phosphate, $0.25 \%$ sodium sulfite and $0.05 \%$ basic fuchsin) with or without 30 $\mu \mathrm{g} / \mathrm{mL}$ kanamycin (KAN) and Congo red agar. The Congo red agar test developed by Freeman et al. (1989) is based on the subculture of the yeast isolates on brain heart infusion agar (BHIA), supplemented with sucrose and Congo red dye and with/without $100 \mu \mathrm{g} / \mathrm{mL}$ vancomycin (VAN). Both media were added with $0-50 \mathrm{mg} / \mathrm{L} \mathrm{CdCl}_{2}$ and the yeast cultures were incubated at $30^{\circ} \mathrm{C}$ for $48-72 \mathrm{~h}$.

\section{B. Effect of lactose on yeast growth}

Endo agar (30 $\mu \mathrm{g} / \mathrm{mL}$ kanamycin) and Congo red agar (100 $\mu \mathrm{g} / \mathrm{mL}$ vancomycin) containing various concentrations of lactose $1-5 \%(\mathrm{w} / \mathrm{v})$ and supplemented with $\mathrm{CdCl}_{2}$ ranged from $0-50 \mathrm{mg} / \mathrm{L}$ was used to detect $\mathrm{CdCl}_{2}$ by yeast. After incubated at $30^{\circ} \mathrm{C}$ for $48-72 \mathrm{~h}$, the change of colony color was observed.

\section{Yeast cell preservation}

The single colony of yeast was grown in NB at $30^{\circ} \mathrm{C}$. The cell pellet was harvested by centrifugation at $7,500 \mathrm{rpm}$ at $4{ }^{\circ} \mathrm{C}$ and the supernatant was discarded. The $10^{9} \mathrm{CFU} / \mathrm{mL}$ cell suspensions were prepared in 5, 10 and $20 \%$ (w/v) skim milk, then $30 \mu \mathrm{L}$ was dropped on the paper disc or $100 \mu \mathrm{L}$ were added into $1.5 \mathrm{~mL}$ polypropylene microtube. Then, the cell suspension was dried either using speed vacuum or freezing at $-70^{\circ} \mathrm{C}$ and followed by freeze dryer for $24 \mathrm{~h}$. After that, they were stored at $4^{\circ} \mathrm{C}$ until used for $\mathrm{Cd}$ detection on 48 well-microtiter plates. 


\section{Cd detection by preserved yeast cell}

For the preserved yeast cell in the polypropylene microtubes, $100 \mu \mathrm{L}$ of LB broth was added and mixed by vortex and incubation $30^{\circ} \mathrm{C}$ for $18 \mathrm{~h}$ and used as a starter. An amount of 10 $\mu \mathrm{L}$ re-suspended starter yeast cells were dropped on the EA and CRA agar and followed by the Cd solution. In contrast, the paper disc immobilized with yeast cells were directly placed on EA and CRA agar and dropped with $\mathrm{Cd}$ solution. After incubation at $30^{\circ} \mathrm{C}$ for 24,48 and $72 \mathrm{~h}$, the change of color colony or paper disc was observed.

\section{RESULTS}

\section{A. Growth and phenotype of yeast}

On Endo agar, the total of 34 yeast isolates were able to grow when untreated with $\mathrm{Cd}$ but 20,2, and 8 isolates did not grow when $12.5,25,50 \mathrm{mg} / \mathrm{L} \mathrm{Cd}$ was present, respectively (Table. I). Four isolates (K10, K15, K30 and K31) were able to grow on Endo agar containing $\mathrm{Cd}$ at concentration higher than $50 \mathrm{mg} / \mathrm{L}$. Fifteen yeast isolates were able to grow when treated or untreated with $\mathrm{Cd}$ on Endo agar with KAN. While five yeast isolates (K9, K11, K12, K26 and K34) grown when untreated with $\mathrm{Cd}$ and showed pink colony but they could not grow at concentration range of $12.5-50 \mathrm{mg} / \mathrm{L}$ (Table. I). Seven isolates (K7, K9, K11, K12, K14, K26 and K34) were able to grow and changed color of colony on Endo agar with various Cd concentration $(0-12.5 \mathrm{mg} / \mathrm{L})$. Three isolates $(\mathrm{K} 9, \mathrm{~K} 11$ and K12) exhibited the red and pink colonies on Endo agar containing $\mathrm{Cd}$ concentration $0-6.25 \mathrm{mg} / \mathrm{L}$ but did not grow when treated with $12.5 \mathrm{mg} / \mathrm{L} \mathrm{Cd}$ (Table. II).

Six isolates were able to grow on Congo red containing $\mathrm{Cd}$ below $50 \mathrm{mg} / \mathrm{L}$, while 28 isolates were able to grow at $\mathrm{Cd}$ concentration above $50 \mathrm{mg} / \mathrm{L}$. K4 is the only isolate that did not grow on Congo red after incubation for $24 \mathrm{~h}$ and a similar result was also observed when tested on Congo red with KAN. The 3 isolates (K12, K14 and K34) exhibited dark red colony on Congo red agar treated with $0-1 \mathrm{mg} / \mathrm{L} \mathrm{Cd}$ but they were pallid red colony when treated with $\mathrm{Cd}$ at the concentration above 5 $\mathrm{mg} / \mathrm{L}$. Three isolates (K7, K9 and K11) showed a dark red colony when treated with Cd concentration below $5 \mathrm{mg} / \mathrm{L}$ after incubation for $48 \mathrm{~h}$ (Fig. 1).

\section{B. Effect of lactose on growth of yeast}

Out of 34, 3 yeast isolates (K7, K11 and K34) developed a red colony on the Endo agar supplemented with 2-4\% (w/v) lactose and untreated $\mathrm{Cd}$ but they exhibited white colonies on medium treated with $\mathrm{Cd}$ concentration above $0.39 \mathrm{mg} / \mathrm{L}$ after incubation for $24 \mathrm{~h}$. The white colony was observed on Endo agar containing 1 and 5\% lactose either with or without $\mathrm{Cd}$. While, 4 isolates (K9, K12, K14 and K26) showed the white colonies when $\mathrm{Cd}$ was above $0.39 \mathrm{mg} / \mathrm{L}$ on Endo agar containing 2-4\% lactose after incubation at $30^{\circ} \mathrm{C}$ for $48 \mathrm{~h}$ (Table III).
TABLE I

CHARACTERISTICS OF 34 YEAST ISOLATES ON ENDO AGAR WITH OR WITHOUT $30 \mu \mathrm{G} / \mathrm{ML}$ KANAMYCIN AND TREATED WITH CADMIUM

\begin{tabular}{|c|c|c|c|c|c|c|c|c|}
\hline \multirow{3}{*}{$\begin{array}{l}\text { Isolate } \\
\mathrm{Cd}(\mathrm{mg} / \mathrm{L})\end{array}$} & \multicolumn{8}{|c|}{ Growth } \\
\hline & \multicolumn{4}{|c|}{ Endo } & \multicolumn{4}{|c|}{ Endo with $30 \mu \mathrm{g} / \mathrm{mL}$ kanamycin } \\
\hline & 0 & 12.5 & 25 & 50 & 0 & 12.5 & 25 & 50 \\
\hline K1 & + & - & - & - & - & - & - & - \\
\hline $\mathrm{K} 2$ & + & + & + & - & + & + & + & + \\
\hline $\mathrm{K} 3$ & + & + & + & - & + & + & + & + \\
\hline K4 & + & - & - & - & - & - & - & - \\
\hline K5 & + & - & - & - & - & - & - & - \\
\hline K6 & + & - & - & - & - & - & - & - \\
\hline K7 & + & - & - & - & + & + & + & + \\
\hline $\mathrm{K} 8$ & + & + & + & - & + & + & + & + \\
\hline K9 & + & - & - & - & + & - & - & - \\
\hline K10 & + & + & + & + & + & + & + & + \\
\hline K11 & + & - & - & - & + & - & - & - \\
\hline $\mathrm{K} 12$ & + & - & - & - & + & - & - & - \\
\hline K13 & + & - & - & - & - & - & - & - \\
\hline K14 & + & - & - & - & + & + & + & + \\
\hline K15 & + & + & + & + & + & + & + & + \\
\hline K16 & + & - & - & - & - & - & - & - \\
\hline K17 & + & - & - & - & - & - & - & - \\
\hline K18 & + & - & - & - & - & - & - & - \\
\hline K19 & + & + & - & - & + & + & + & + \\
\hline K20 & + & + & + & - & + & + & + & + \\
\hline $\mathrm{K} 21$ & + & + & + & - & + & + & + & + \\
\hline $\mathrm{K} 22$ & + & + & + & - & + & + & + & + \\
\hline $\mathrm{K} 23$ & + & + & + & - & + & + & + & + \\
\hline K24 & + & + & - & - & - & - & - & - \\
\hline $\mathrm{K} 25$ & + & - & - & - & - & - & - & - \\
\hline $\mathrm{K} 26$ & + & - & - & - & + & - & - & - \\
\hline $\mathrm{K} 27$ & + & - & - & - & - & - & - & - \\
\hline K28 & + & - & - & - & - & - & - & - \\
\hline K29 & + & + & + & - & + & + & + & + \\
\hline K30 & + & + & + & + & + & + & + & + \\
\hline K31 & + & + & + & + & + & + & + & + \\
\hline K32 & + & - & - & - & - & - & - & - \\
\hline K33 & + & - & - & - & - & - & - & - \\
\hline K34 & + & - & - & - & + & - & - & - \\
\hline \multicolumn{9}{|c|}{ Colony color: + growth, - no growth. } \\
\hline \multicolumn{9}{|c|}{$\begin{array}{c}\text { TABLE II } \\
\text { PHENOTYPE OF } 7 \text { YEAST ISOLATES WHEN GROWN ON ENDO } \\
\text { AGAR (1\% LACTOSE) AFTER INCUBATION AT 30 } 30^{\circ} \mathrm{C} \text { FOR } 24 \mathrm{H} .\end{array}$} \\
\hline \multirow[t]{2}{*}{ Isolates } & \multicolumn{8}{|c|}{ Cd concentration $(\mathrm{mg} / \mathrm{L})$} \\
\hline & 0 & & 1.56 & & 3.12 & 6.25 & & 12.5 \\
\hline K7 & colorles & & colorles: & & colorless & colorless & & no growth \\
\hline K9 & red & & pink & & pink & pink & & no growth \\
\hline K11 & red & & pink & & pink & pink & & no growth \\
\hline $\mathrm{K} 12$ & red & & pink & & pink & pink & & no growth \\
\hline K14 & colorles & & colorles & & colorless & colorless & & no growth \\
\hline K26 & colorles & & colorles & & colorless & colorless & & no growth \\
\hline $\mathrm{K} 34$ & colorles & & colorles & & colorless & colorless & & no growth \\
\hline
\end{tabular}

\section{Cell stability}

The survival of K9, K11 and K12 on the paper disc and the polypropylene microtubes showed a similar result and the number of viable cells was not different. The cells preserved with 5, 10 and 20\% (w/v) skim milk and immobilized on polypropylene microtubes were able to survive better when dried using freeze dryer compared with a speed vacuum. While the cell survival was not different when preserved with 5,10 and $20 \%$ skim milk.

The preserved cell on microtube of $\mathrm{K} 9$ and $\mathrm{K} 11$ were able to change from orange to red color on Congo red agar containing 
$100 \mu \mathrm{g} / \mathrm{mL}$ vancomycin and supplemented with $0-1 \mathrm{mg} / \mathrm{L} \mathrm{Cd}$ after incubation at $30^{\circ} \mathrm{C}$ for $48 \mathrm{~h}$. The $\mathrm{K} 12$ isolate was able to change from pink to red colony on Endo agar treated with $\mathrm{Cd}$ concentration at $0.1 \mathrm{mg} / \mathrm{L}$ or higher and showed a similar result between Endo agar with or without $30 \mu \mathrm{g} / \mathrm{mL}$ kanamycin (Fig. 2). In contrast, the yeast cell immobilized on paper disc did not show any changes in color. between untreated and treated $\mathrm{Cd}$. The highest sensitivity was observed when a starter was prepared from the cells preserved on polypropylene microtube and the fresh culture was then tested for Cd detection.

$$
\text { TABLE III }
$$

DETECTION LIMIT OF CADMIUM (MG/L) BY 6 YEAST ISOLATES WHEN GROWN ON ENDO AGAR WITH 1-5\% LACTOSE AFTER INCUBATION AT $30^{\circ} \mathrm{C}$ FOR $24 \mathrm{H}$.

\begin{tabular}{lccccc}
\hline \hline \multirow{2}{*}{ Isolates } & \multicolumn{5}{c}{ Lactose (w/v) } \\
\cline { 2 - 6 } & $1 \%$ & $2 \%$ & $3 \%$ & $4 \%$ & $5 \%$ \\
\hline $\mathrm{K} 7$ & $>12.5$ & $<0.39$ & $<0.39$ & $<0.39$ & $<12.5$ \\
$\mathrm{~K} 9$ & $>12.5$ & $<12.5$ & $<12.5$ & $<12.5$ & $<12.5$ \\
$\mathrm{~K} 11$ & $>12.5$ & $<0.39$ & $<12.5$ & $<12.5$ & $<12.5$ \\
$\mathrm{~K} 12$ & $>12.5$ & $<12.5$ & $<12.5$ & $<12.5$ & $<12.5$ \\
$\mathrm{~K} 14$ & $>12.5$ & $<12.5$ & $<12.5$ & $<12.5$ & $<12.5$ \\
$\mathrm{~K} 26$ & $>12.5$ & $<12.5$ & $<12.5$ & $<12.5$ & $<12.5$ \\
$\mathrm{~K} 34$ & $>12.5$ & $<0.39$ & $<0.39$ & $<0.39$ & $<12.5$ \\
\hline \hline
\end{tabular}

\section{DISCUSSION}

K12 produced red colony due to the ability to ferment lactose on Endo agar containing $30 \mu \mathrm{g} / \mathrm{mL}$ kanamycin and $\mathrm{Cd}$ below $0.1 \mathrm{mg} / \mathrm{L}$. Normally, yeast produces pink colony when grown under lactose fermentation. K12 exhibited colorless on Endo agar supplemented with $\mathrm{Cd}$ at higher concentration than 0.1 $\mathrm{mg} / \mathrm{L}$ suggesting that $\mathrm{Cd}$ might be slightly toxic to yeast. It has been reported that many heavy metals are toxic to yeast cell during fermentation processes including copper, cobalt, cadmium, zinc, arsenic and lead [8]. However, the degree of toxicity depends on type, concentration and bioavailability of heavy metals.

K9 and K11 showed dark red colony on Congo red agar with $100 \mu \mathrm{g} / \mathrm{mL}$ vancomycin when treated Cd concentration below 5 $\mathrm{mg} / \mathrm{L}$. It has been reported that when yeasts produced a biofilm on Congo red, they showed many colony colors from brown to black. K9 and K11 showed colony colors ranging from red to dark red, indicating that they were the non-biofilm producers [9]. The cations can promote the biofilm formation by facilitating exopolysaccharide polymerization in Staphylococcus epidermidis [10]. The colony color modification of yeast was observed on Congo red when added with $\mathrm{Cd}$ suggests that at higher concentration, $\mathrm{Cd}$ may have the effects on growth and induction of biofilm formation. Hence, $\mathrm{K} 9$ and $\mathrm{K} 11$ are the potential isolates that should be further investigated under other growth conditions. (a)

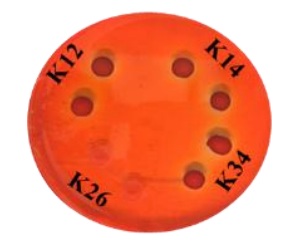

Untreated-Cd

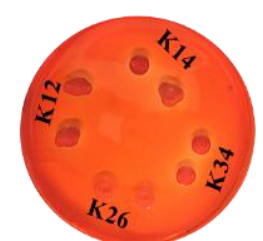

Treated-Cd $5 \mathrm{mg} / \mathrm{L}$ (b)

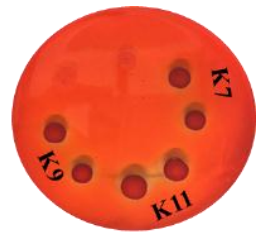

Untreated-Cd

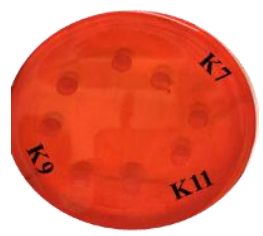

Treated-Cd $10 \mathrm{mg} / \mathrm{L}$
Fig. 1 Phenotypic characterization of 7 yeast isolates (a) K12, K14 and K34 immobilized on microtube exhibited dark red colony on Congo red agar with untreated $\mathrm{Cd}$ but pale color on agar treated with $5 \mathrm{mg} / \mathrm{L} \mathrm{Cd}$, (b) $\mathrm{K} 7, \mathrm{~K} 9$ and $\mathrm{K} 11$ showed dark red colony on agar with untreated $\mathrm{Cd}$ but pale colony when treated with $10 \mathrm{mg} / \mathrm{L} \mathrm{Cd}$ after $48 \mathrm{~h}$.

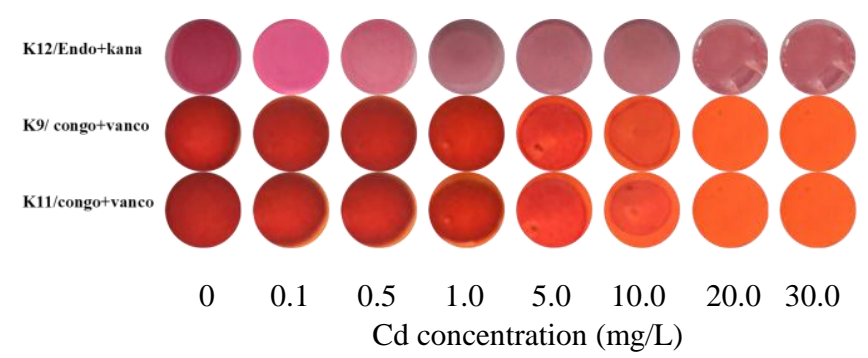

Fig. 2 Color change of $\mathrm{K} 9, \mathrm{~K} 11$ and $\mathrm{K} 12$ when cells preserved on microtube were used as starters and tested on Endo agar and Congo red when tested with $0-30 \mathrm{mg} / \mathrm{L} \mathrm{Cd}$ after incubation at $30^{\circ} \mathrm{C}$ for $48 \mathrm{~h}$.

\section{CONCLUSION}

$\mathrm{K} 9, \mathrm{~K} 11$ and $\mathrm{K} 12$ are the interesting yeast isolates because they behave and response differently to $\mathrm{Cd}$. These 3 isolates changed colony color on Endo agar and Congo red when $\mathrm{Cd}$ was present at a certain concentration. The detection limit of $\mathrm{Cd}$ by $\mathrm{K} 12$ on Endo agar was below $0.1 \mathrm{mg} / \mathrm{L}$ after incubation at $30^{\circ} \mathrm{C}$ for $48 \mathrm{~h}$. The phenotypic properties of some yeast isolates when grown under certain level of $\mathrm{Cd}$ observed in this study can be easily observed and defined, however their specificity on $\mathrm{Cd}$ has not yet been investigated. Thus, the genotypic features of yeast in response to $\mathrm{Cd}$ could give more supportive information and eventually, the detection tool could be developed and applied for the measurement of $\mathrm{Cd}$ in the contaminated samples.

\section{ACKNOWLEDGMENT}

We thank Research Fund for Supporting Lecturer to Admit High Potential Student to Study and Research on His Expert Program Year 2015, Khon Kean University, Thailand.

\section{REFERENCES}

[1] B. J. Alloway, Introduction. In Heavy Metals in Soils: Trace Metals and Metalloids in Soils and Their Bioavailability. Berlin, Germany: Springer, 2013, pp. 3-9.

https://doi.org/10.1007/978-94-007-4470-7 https://doi.org/10.1007/978-94-007-4470-7_1

[2] M. Monachese, J. P. Burton, and G. Reid, “ Bioremediation and tolerance of humans to heavy metals through microbial processes: a potential role for probiotics?," Applied and environmental microbiology, vol. 78, no. 18, pp. 6397-6404, 2012.

https://doi.org/10.1128/AEM.01665-12 
[3] H. Doshi, A. Ray, and I. Kothari, "Biosorption of cadmium by live and dead Spirulina: IR spectroscopic, kinetics, and SEM studies, " Curr. Microbiol, vol. 54, pp. 213-218, 2007. https://doi.org/10.1007/s00284-006-0340-y

[4] J. Godt, F. Scheidig, C. Grosse-Siestrup, V. Esche, P. Brandenburg, A. Reich, and D. A.Groneberg. "The toxicity of cadmium and resulting hazards for human health," Journal of occupational medicine and toxicology; vol. 1, 2006.

[5] Q. Hurdebise, C. Tarayre, C. Fischer, G. Colinet, S. Hiligsmann, and F. Delvigne, "Determination of zinc, cadmium and lead bioavailability in contaminated soils at the single-cell level by a combination of whole-cell biosensors and flow cytometry," Sensors, vol. 15, no. 4, pp. 8981-8999, 2015. https://doi.org/10.3390/s150408981

[6] I. Vopálenská, L. Váchová, and Z. Palková, “New biosensor for detection of copper ions in water based on immobilized genetically modified yeast cells," Biosensors and Bioelectronics, vol. 72, pp. 160-167, 2015. https://doi.org/10.1016/j.bios.2015.05.006

[7] H. Strosnider, "Whole-cell bacterial biosensors and the detection of bioavailable arsenic," US Environmental Protection Agency, 2003.

[8] G. M. Walker, "Metals in yeast fermentation processes," Advances in applied microbiology, vol. 54, pp. 197-230, 2004. https://doi.org/10.1016/S0065-2164(04)54008-X

[9] T. D. Kaiser, E. M. Pereira, K. R. Dos Santos, E. L. Maciel, R. P. Schuenck, A. P. Nunes. "Modification of the Congo red agar method to detect biofilm production by Staphylococcus epidermidis,". Diagn Microbiol Infect Dis., vol. 75, pp. 235-9, 2013. https://doi.org/10.1016/j.diagmicrobio.2012.11.014

[10] N. Ö. Akpolat, S. Elci, S. Atmaca, H. Akbayin, and K. Gül, “The effects of magnesium, calcium and EDTA on slime production byStaphylococcus epidermidis strains," Folia microbiologica, vol. 48, pp. 649, 2003.

https://doi.org/10.1007/BF02993473 